\title{
Chronotropic Incompetence Limits Aerobic Exercise Capacity in Patients Taking Beta-Blockers
}

\author{
Maciej Tysarowski MD ${ }^{1,2, *}$; Krzysztof Smarz MD; PhD ${ }^{1, *}$; Beata Zaborska MD, PhD; \\ Ewa Pilichowska-Paszkiet MD, $\mathrm{PhD}^{1}$; Malgorzata Sikora-Frac MD, $\mathrm{PhD}^{1}$; Andrzej Budaj \\ $\mathrm{MD}, \mathrm{PhD}^{1}$; Tomasz Jaxa-Chamiec MD, $\mathrm{PhD}^{1}$ \\ 1Department of Cardiology, Centre of Postgraduate Medical Education, Grochowski Hospital, Warsaw, \\ Poland \\ 2Department of Medicine, Rutgers University New Jersey Medical School, Newark, New Jersey \\ *Both Dr. Tysarowski and Dr. Smarz contributed equally as first authors to this study
}

\section{Corresponding author:}

Krzysztof Smarz MD, PhD, Department of Cardiology, Centre of Postgraduate Medical Education, Grochowski Hospital, Grenadierow 51/59, 04-073 Warsaw, Poland

Phone/fax number: 48-22-810-1738

Email: krzysztofsmarz@hotmail.com

\section{Funding information:}

Centre of Postgraduate Medical Education, Warsaw, Poland;

Grant/Award Number: 501-1-10-14-13

\section{Conflict of interest:}

The authors declare no potential conflict of interest

\section{Abstract word count: 230}

Manuscript word count: 2303

Manuscript pages: 20

Number of tables: 3

Number of figures: 2

Number of references: 32 


\section{ABSTRACT}

Background: Chronotropic incompetence in patients taking beta-blockers is associated with poor prognosis; however, its impact on exercise capacity $(E C)$ remains unclear.

Methods: We retrospectively analyzed data from consecutive patients taking betablockers referred for cardiopulmonary exercise testing. EC was expressed as peak oxygen uptake (peak VO$; ~ \mathrm{~mL} / \mathrm{kg} / \mathrm{min}$ ). Chronotropic incompetence was defined as chronotropic index $(\mathrm{Cl}) \leq 62 \%$. Cl was calculated as [(HR at peak-HR at rest $)$ / (maximum predicted $\mathrm{HR}-\mathrm{HR}$ at rest)] $\times 100 \%$.

Results: Among 140 patients all taking beta-blockers (age $61 \pm 9.7$ years; $73 \%$ males), there were $113(80.7 \%)$ patients with chronotropic incompetence. EC was lower in the group with chronotropic incompetence than the group without it, peak $\mathrm{VO}_{2} 18.3 \pm 5.7 \mathrm{vs}$. $24.0 \pm 5.3 \mathrm{~mL} / \mathrm{kg} / \mathrm{min}, \mathrm{p}<0.001$. In multivariate analysis $\mathrm{EC}$ correlated positively with $\mathrm{Cl}$ $(\beta=0.14, p<0.001)$ and male gender $(\beta=5.12, p<0.001)$, and negatively with age $(\beta$ $=-0.17, p<0.001)$ and presence of heart failure $(\beta=-3.35, p<0.001)$. Beta-blocker dose was not associated with EC. Partial correlation attributable to $\mathrm{Cl}$ accounted for more than one-third of the variance in EC explained by the model.

Conclusions: In patients taking beta-blockers, presence of chronotropic incompetence was associated with lower EC, regardless of the beta-blocker dose. $\mathrm{Cl}$ accounted for more than one-third of EC variance explained by our model. 


\title{
KEY WORDS
}

adrenergic beta antagonists; chronotropic incompetence; chronotropic index; exercise capacity; exercise test; oxygen uptake

\author{
ABBREVIATION LIST \\ $\mathrm{Cl}$, chronotropic index \\ EC, exercise capacity \\ $\mathrm{HR}$, heart rate \\ $\mathrm{VO}_{2}$, oxygen uptake
}

\section{HIGHLIGHTS}

- Patients on beta blockers with chronotropic incompetence have lower exercise capacity

- Beta-blocker dose is not associated with exercise capacity

- We recommend incorporating chronotropic index into exercise stress testing 
medRxiv preprint doi: https://doi.org/10.1101/2020.07.15.20149005; this version posted July 17, 2020. The copyright holder for this preprint

(which was not certified by peer review) is the author/funder, who has granted medRxiv a license to display the preprint in perpetuity.

It is made available under a CC-BY-NC-ND 4.0 International license .

\section{INTRUDUCTION}

Chronotropic incompetence is defined as an inadequate increase in heart rate $(\mathrm{HR})$ during exercise. The presence of chronotropic incompetence is associated with poor prognosis in both symptomatic and asymptomatic patients. ${ }^{1-6}$ The frequency of chronotropic incompetence depends on the definition used as well as the population examined and ranges from $9 \%$ to $89 \% .{ }^{7}$ The Euro-EX prevention trial reported that, among healthy individuals, chronotropic incompetence assessed as an inability to achieve $80 \%$ of the age-predicted HR reserve, was present in $70 \%$ of patients. ${ }^{8}$ While chronotropic incompetence in patients not treated with beta-blockers is correlated with reduced exercise capacity (EC), ${ }^{9}$ data from patients taking beta-blockers are ambiguous. Furthermore, in studies aimed at assessing chronotropic response and EC, chronotropic incompetence was most commonly defined as an inability to reach $80 \%$ of $\mathrm{Cl}$ or $80 \%$ of the maximum predicted $\mathrm{HR}$ regardless of beta-blockers treatment, and only few of them were focused on patients treated with beta-blockers. ${ }^{10-13}$

Identifying factors responsible for low EC may be relevant for patient evaluation and management, ${ }^{14}{ }^{15}$ because its strong predictive value for all-cause and cardiovascular mortality in patients with and also without heart failure. ${ }^{16}$ In a study of 3736 consecutive patients with normal electrocardiograms who were taking betablockers (either metoprolol or atenolol), chronotropic incompetence defined as a $\mathrm{Cl} £$ $62 \%$ was an independent predictor of all-cause mortality (adjusted hazard ratio 1.94, $95 \%$ confidence interval 1.43 to $2.64, p<0.0001$ ) in 4.5 years follow-up. ${ }^{3}$ Based on this assumption, this cut-off value is recommended in the guidelines for chronotropic incompetence diagnosis in patients treated with beta-blockers, ${ }^{16}$ but this value has not been validated as a predictor of low EC.

Therefore, we planned our study to assess the relationship between chronotropic incompetence and EC in patients treated with beta-blockers.

\section{METHODS}

\subsection{Study population and inclusion criteria}

We retrospectively analyzed data from consecutive patients who were referred for an exercise tolerance assessment at the Exercise Physiology Laboratory at the Cardiology Department, Centre of Postgraduate Medical Education, Grochowski Hospital, Warsaw, Poland, between January 2008 and June 2016.

We included patients treated with beta-blockers starting at least 4 weeks before cardiopulmonary exercise testing as presented in Fig. 1. Exclusion criteria were pulmonary or peripheral limitations of exercise, hemodynamically significant valve dysfunction or pulmonary hypertension, heart failure in New York Heart Association 
medRxiv preprint doi: https://doi.org/10.1101/2020.07.15.20149005; this version posted July 17, 2020. The copyright holder for this preprint (which was not certified by peer review) is the author/funder, who has granted medRxiv a license to display the preprint in perpetuity. It is made available under a CC-BY-NC-ND 4.0 International license .

functional class IV, hospitalization for acute coronary syndromes or decompensated heart failure within the past 30 days, exercise-induced ischemia, insufficient effort (respiratory exchange ratio $<1.05$ at peak exercise), heart rhythm other than sinus during cardiopulmonary exercise test, and pacemaker implantation. Patients included in the study were divided into two groups: with and without chronotropic incompetence.

Data on patients' demographic and clinical details, laboratory tests, medications, and comorbidities were obtained from hospital patient medical documentation.

Comorbidities were established based on physicians' diagnoses from electronic medical records. Creatinine clearance was calculated using Cockcroft-Gault equation. Daily doses of beta-blockers were calculated as bisoprolol equivalent dose. Dose equivalents for beta-blockers were derived from the European Society of Cardiology Guidelines for the diagnosis and treatment of acute and chronic heart failure. ${ }^{17}$ Doses were calculated as bisoprolol $10 \mathrm{mg}$ daily equivalent to: carvedilol $25 \mathrm{mg}$ twice daily (BID); metoprolol tartrate 100 mg BID; metoprolol succinate 200 mg daily; nebivolol 10 mg daily; and sotalol $160 \mathrm{mg}$ BID.

\subsection{Echocardiography}

All assessed echocardiographic studies were performed during routine evaluation by cardiologists experienced in cardiovascular imaging, and all measurements were performed according to recommendations of the American Society of Echocardiography and the European Association of Cardiovascular Imaging. ${ }^{18-20}$ Patients were characterized using the following echocardiographic parameters: left ventricular end-diastolic dimension; anteroposterior dimension of the left atrium from parasternal long-axis view; basal right ventricular end-diastolic dimension and minoraxis dimension of the right atrium from four-chamber view; left ventricular ejection fraction from the biplane method of discs (modified Simpson's rule); visual assessment of segmental contraction disturbances as (1) normal or hyperkinetic, (2) hypokinetic, (3) akinetic, and (4) dyskinetic; calculated wall motion score index (16 segments model); left ventricular diastolic dysfunction with grade 1, 2, or 3 dysfunction based on mitral inflow parameters; and right ventricular systolic dysfunction diagnosed in patients with tricuspid plane systolic excursion $<17 \mathrm{~mm}$.

\subsection{Cardiopulmonary exercise test}

All patients performed a symptom-limited cardiopulmonary exercise test using a treadmill or cycle ergometer with Schiller Cardiovit CS-200 (Schiller, Baar, Switzerland) and Ergo Spiro adapter (Garnshorn, Nederlauer, Germany), with the incremental protocol selected according to the individual's physical condition to maintain the duration of exercise between 8 and $12 \mathrm{~min}$. All patients were familiar with the exercise 
medRxiv preprint doi: https://doi.org/10.1101/2020.07.15.20149005; this version posted July 17, 2020. The copyright holder for this preprint (which was not certified by peer review) is the author/funder, who has granted medRxiv a license to display the preprint in perpetuity. It is made available under a CC-BY-NC-ND 4.0 International license .

protocol and were encouraged to perform maximal effort ( $\geq 8$ points using the 10-point Borg scale). All exercise tests were performed and analyzed by the same physician according to the guidelines of the American College of Cardiology/American Heart Association and the American Thoracic Society/American College of Chest Physicians. ${ }^{14162122}$ The system was calibrated each day before performing the tests. Ventilation, $\mathrm{VO}_{2}$ uptake, and carbon dioxide output during exercise were analyzed breath by breath. Peak $\mathrm{VO}_{2}(\mathrm{~mL} / \mathrm{kg} / \mathrm{min})$ was averaged from measurements taken during the last $20 \mathrm{~s}$ of exercise and was assessed as an EC parameter. The anaerobic threshold was calculated using a dual method approach (V-slope and ventilatory equivalent methods). Maximum predicted $\mathrm{VO}_{2}$ values were calculated using the Wasserman/Hansen equation. ${ }^{23}$

Chronotropic incompetence was defined as chronotropic index $(\mathrm{Cl}) \leq 62 \%,{ }^{3}$ calculated as percentage of HR reserve as follows:

$$
\frac{H R \text { at peak exercise }-H R \text { at rest }}{\text { Maximum predicted } H R-H R \text { at rest }} \times 100 \% \text {. }
$$

Maximum predicted HR was calculated as 220 - age, as previously defined by Astrand et al. ${ }^{24}$ Percent of predicted maximum HR achieved at peak exercise and HR reserve, defined as the change in HR from rest to peak were also calculated.

Other analyzed cardiopulmonary exercise testing parameters included systolic blood pressure at rest and at peak exercise, ventilatory efficiency (minute ventilation versus carbon dioxide production slope), and breathing reserve at peak exercise, calculated as the percentage of maximal voluntary ventilation used [(maximal voluntary ventilation - minute ventilation at peak exercise)/maximal voluntary ventilation] $\times 100 \%$. Resting spirometry parameters, calculated as forced expiratory volume in $1 \mathrm{~s}$., and inspiratory vital capacity were also recorded.

\subsection{Statistical methods}

Data were presented as mean \pm standard deviation for normally distributed or median (25th and 75th percentiles) for non-normally distributed continuous variables. Categorical variables were presented as a number (percentage). Normality for all continuous variables was tested using the Shapiro-Wilk test. Group comparisons were performed using Student's $t$ test or Mann-Whitney test for continuous variables and $\mathrm{x} 2$ (chi-squared) test for categorical variables. Univariate and multivariate linear regression analyses were performed to establish the association between independent variables and EC. Peak $\mathrm{VO}_{2}(\mathrm{~mL} / \mathrm{kg} / \mathrm{min})$ was used as the dependent variable for all models. Logarithmic transformation was used for non-normally distributed variables when analyzed in regression models. Variables for the univariate and multivariate models 
medRxiv preprint doi: https://doi.org/10.1101/2020.07.15.20149005; this version posted July 17, 2020. The copyright holder for this preprint (which was not certified by peer review) is the author/funder, who has granted medRxiv a license to display the preprint in perpetuity.

It is made available under a CC-BY-NC-ND 4.0 International license .

were selected using the Akaike Information Criterion and stepwise linear regression model. Variables with well-known effects on EC were forced into the model. All statistical tests were two-sided. Statistical significance was established as $\alpha=0.05$, and all statistical analyses were performed using R Statistical Software version 3.6.1.

\subsection{Ethics}

This study was conducted following the requirements set out in the Declaration of Helsinki. All patients provided written consent to take part in the cardiopulmonary exercise test. The study protocol was approved by the Center of Postgraduate Medical Education's Institutional Review Board, and individual consent to participate in retrospective anonymous data analysis was waived.

\section{RESULTS}

Among 367 evaluated patients, 268 were treated with beta-blockers and 140 fulfilled the inclusion criteria. The flow chart of patient selection is presented in Fig. 1.

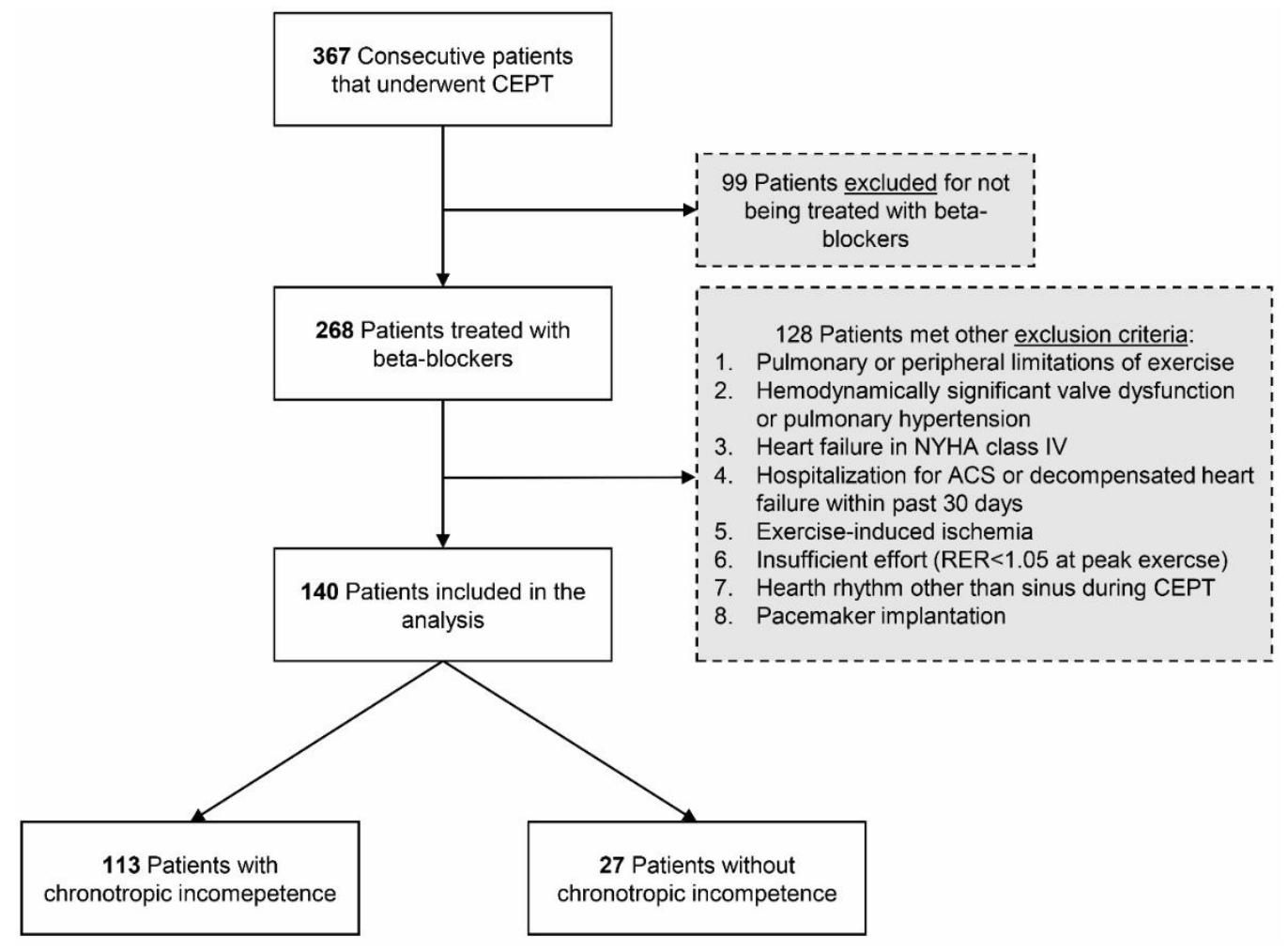

Fig. 1. Study flow chart.

Abbreviations: ACS, acute coronary syndrome; CPET, cardiopulmonary exercise test; NYHA, New York Heart Association functional classification; RER, respiratory exchange ratio. 
The baseline characteristics of the patients are presented in Table 1. Among 140 patients all taking beta-blockers, mean age was $61 \pm 9.7$ years and $73 \%$ were males. There were $113(81 \%)$ patients in the group with chronotropic incompetence and 27 (19\%) patients in the group without chronotropic incompetence. Diabetes mellitus and impaired fasting glucose were more frequent in the group with chronotropic incompetence. Daily dose of beta-blockers was higher, and serum creatinine levels were lower in the group with chronotropic incompetence, and there were no differences in creatinine clearance between the two groups. No statistically significant differences were observed for other demographic and clinical parameters between the two groups.

The echocardiographic parameters are also presented in Table 1. No differences were observed for left and right ventricular function and chambers dimensions between the two groups. Median time between echocardiography and cardiopulmonary exercise testing was 4 weeks.

Table 1

Baseline characteristics of study participants.

\begin{tabular}{|c|c|c|c|c|}
\hline & \multirow{2}{*}{$\begin{array}{l}\text { All patients } \\
(n=140)\end{array}$} & \multicolumn{2}{|c|}{ "Chronotropic incompetence ${ }^{a}$} & \multirow[b]{2}{*}{ p-value } \\
\hline & & $\begin{array}{l}\text { Yes } \\
(n=113)\end{array}$ & $\begin{array}{l}\text { No } \\
(n=27)\end{array}$ & \\
\hline \multicolumn{5}{|l|}{ Demographics } \\
\hline Age, years & $61.0 \pm 9.7$ & $60.7 \pm 10.0$ & $62.1 \pm 8.5$ & 0.525 \\
\hline Male sex, $\mathrm{n}(\%)$ & $102(73)$ & $78(69)$ & $24(89)$ & 0.065 \\
\hline $\mathrm{BMI}, \mathrm{kg} / \mathrm{m}^{2}$ & $27.8 \pm 4.1$ & $27.8 \pm 4.0$ & $27.7 \pm 4.5$ & 0.953 \\
\hline \multicolumn{5}{|l|}{ Comorbidity, n (\%) } \\
\hline NYHA functional class & $89(64)$ & $74(65)$ & $15(56)$ & 0.514 \\
\hline 1 & $71(51)$ & $59(52)$ & $12(44)$ & 0.609 \\
\hline II & $8(6)$ & $7(6)$ & $1(4)$ & 0.968 \\
\hline III & $10(7)$ & $8(7)$ & $2(7)$ & 0.968 \\
\hline CAD & $115(82)$ & $94(83)$ & $21(78)$ & 0.704 \\
\hline Ml & $110(79)$ & $90(80)$ & $20(74)$ & 0.709 \\
\hline Coronary angiography & $118(84)$ & $96(85)$ & $22(81)$ & 0.88 \\
\hline $\mathrm{PCl}$ & $107(76)$ & $87(77)$ & $20(74)$ & 0.945 \\
\hline CABG & $5(4)$ & $4(4)$ & $1(4)$ & 1 \\
\hline DM/IFG & $29(20)$ & $28(24)$ & $1(4)$ & 0.033 \\
\hline Hypertension & $88(63)$ & $74(65)$ & $14(52)$ & 0.273 \\
\hline Current smoker & $42(30)$ & $35(31)$ & $7(26)$ & 0.779 \\
\hline Paroxysmal atrial fibrillation & $14(10)$ & $12(11)$ & $2(7)$ & 0.886 \\
\hline \multicolumn{5}{|l|}{ Biochemistry } \\
\hline Hemoglobin, g/L & $13.8 \pm 1.5$ & $13.8 \pm 1.5$ & $13.8 \pm 1.5$ & 0.934 \\
\hline Serum creatinine (IQR), mg/dL & $0.9(0.8-1.1)$ & $0.9(0.8-1.1)$ & $1.1(0.9-1.3)$ & 0.005 \\
\hline
\end{tabular}




\begin{tabular}{|c|c|c|c|c|}
\hline Creatinine clearance, $\mathrm{mL} / \mathrm{min} / 1.73 \mathrm{~m}^{2}$ & $95 \pm 30$ & $97 \pm 31$ & $88 \pm 29$ & 0.188 \\
\hline \multicolumn{5}{|l|}{ Medication, n (\%) } \\
\hline Bisoprolol & $77(55)$ & $67(59)$ & $10(37)$ & 0.061 \\
\hline Metoprolol & $49(35)$ & $35(31)$ & $14(52)$ & 0.069 \\
\hline Carvedilol & $9(6)$ & $7(6)$ & $2(7)$ & 1 \\
\hline Sotalol & $2(1)$ & $2(2)$ & $0(0)$ & 1 \\
\hline Nebivolol & $2(1)$ & $1(1)$ & $1(4)$ & 0.837 \\
\hline Other heart rate lowering drugs ${ }^{b}$ & $8(6)$ & $16(14)$ & $2(7)$ & 1 \\
\hline Dihydropyridine CCB & $18(13)$ & $16(14)$ & $2(7)$ & 0.554 \\
\hline ACEI/ARB & $111(79)$ & $92(81)$ & $19(70)$ & 0.313 \\
\hline Diuretics & $35(25)$ & $30(27)$ & $5(19)$ & 0.536 \\
\hline BB dose, bisoprolol equivalent (IQR), mg & $2.5(2.5-5)$ & $2.5(2.5-5.0)$ & $2.5(1.2-2.5)$ & 0.033 \\
\hline \multicolumn{5}{|l|}{ Echocardiography } \\
\hline LV end-diastolic dimension, $\mathrm{mm}$ & $47(44-50)$ & $46.0(44-50)$ & $47(44-50)$ & 0.523 \\
\hline Left atrium dimension, $\mathrm{mm}$ & $40 \pm 5$ & $40 \pm 5$ & $39 \pm 5$ & 0.558 \\
\hline LVEF, \% & $53.3 \pm 11.6$ & $53.4 \pm 11.9$ & $52.8 \pm 10.5$ & 0.816 \\
\hline WMSI (IQR) & $1.4(1.1-1.7)$ & $1.4(1.1-1.8)$ & $1.5(1.0-1.6)$ & 0.940 \\
\hline LV diastolic dysfunction, n (\%) & & & & 0.702 \\
\hline Grade 1 & $114(81)$ & $90(80)$ & $24(89)$ & 0.404 \\
\hline Grade 2 & $8(6)$ & $7(6)$ & $1(4)$ & 0.968 \\
\hline Grade 3 & $2(1)$ & $2(2)$ & $0(0)$ & 1 \\
\hline MR moderate, $\mathrm{n}(\%)$ & $33(24)$ & $25(22)$ & $8(30)$ & 0.567 \\
\hline RV end-diastolic dimension (IQR), $\mathrm{mm}$ & $34(30-36)$ & $34(29-36)$ & $35(32-38)$ & 0.096 \\
\hline Right atrium dimension, $\mathrm{mm}$ & $35 \pm 6$ & $36 \pm 6$ & $34 \pm 5$ & 0.267 \\
\hline RV systolic dysfunction, $\mathrm{n}(\%)$ & $38(27)$ & $33(29)$ & $5(19)$ & 0.378 \\
\hline TR moderate, $\mathrm{n}(\%)$ & $11(8)$ & $9(8)$ & $2(7)$ & 1 \\
\hline
\end{tabular}

Note: Values represent mean \pm SD, median (IQR; $25^{\text {th }}-75^{\text {th }}$ percentiles), or number $(\%)$. Bold values indicate statistical significance.

Abbreviations: ACEI / ARB, angiotensin-converting enzyme inhibitor/angiotensin receptor blocker; BB, beta-blocker; BMI, body mass index; CABG, coronary artery bypass grafting; CAD, coronary artery disease; CCB, calcium channel blocker; DM / IFG, diabetes mellitus / impaired fasting glucose; IQR, interquartile range; LV, left ventricle; LVEF, left ventricular ejection fraction; MI, history of myocardial infarction; MR, mitral regurgitation; NYHA, New York Heart Association functional classification; $\mathrm{PCl}$, percutaneous coronary intervention; RV, right ventricle; TR, tricuspid regurgitation; WMSI, wall motion score index.

${ }^{a}$ defined as chronotropic index $\leq 62 \%$.

${ }^{b}$ non-dihydropyridine calcium channel blockers, amiodarone, propafenone, ivabradine, and digoxine

\section{Cardiopulmonary exercise testing results are shown in Table 2. The $\mathrm{Cl}$ for all} patients was $48.6 \% \pm 17.3 \%$, lower in the group with chronotropic incompetence $42.7 \%$ $\pm 13.0 \%$ vs. $73.1 \% \pm 9.3 \%$ in the group without chronotropic incompetence. The group with chronotropic incompetence also had a significantly lower percentage of maximum predicted HR achieved at peak exercise compared with the group without chronotropic incompetence. 
medRxiv preprint doi: https://doi.org/10.1101/2020.07.15.20149005; this version posted July 17, 2020. The copyright holder for this preprint (which was not certified by peer review) is the author/funder, who has granted medRxiv a license to display the preprint in perpetuity. It is made available under a CC-BY-NC-ND 4.0 International license .

EC expressed as peak $\mathrm{VO}_{2}$ was $19.4 \pm 6.1 \mathrm{~mL} / \mathrm{kg} / \mathrm{min}$ for all patients, lower in the group with chronotropic incompetence compared with the group without chronotropic incompetence $(18.3 \pm 5.7 \mathrm{~mL} / \mathrm{kg} / \mathrm{min}$ vs. $24.0 \pm 5.3 \mathrm{~mL} / \mathrm{kg} / \mathrm{min}, \mathrm{p}<0.001)$. The percentages of maximum predicted $\mathrm{VO}_{2}$ and $\mathrm{VO}_{2}$ at the anaerobic threshold were also significantly lower in the group with chronotropic incompetence. Peak $\mathrm{VO}_{2}$ was, $21.3 \pm$ $5.3 \mathrm{~mL} / \mathrm{kg} / \mathrm{min}$ for males, and $14.3 \pm 4.9 \mathrm{~mL} / \mathrm{kg} / \mathrm{min}$ for females, $p<0.001$.

Fig. 2 shows there was a moderately strong $(r=0.55)$, positive linear association between $\mathrm{Cl}$ and $\mathrm{EC}$.

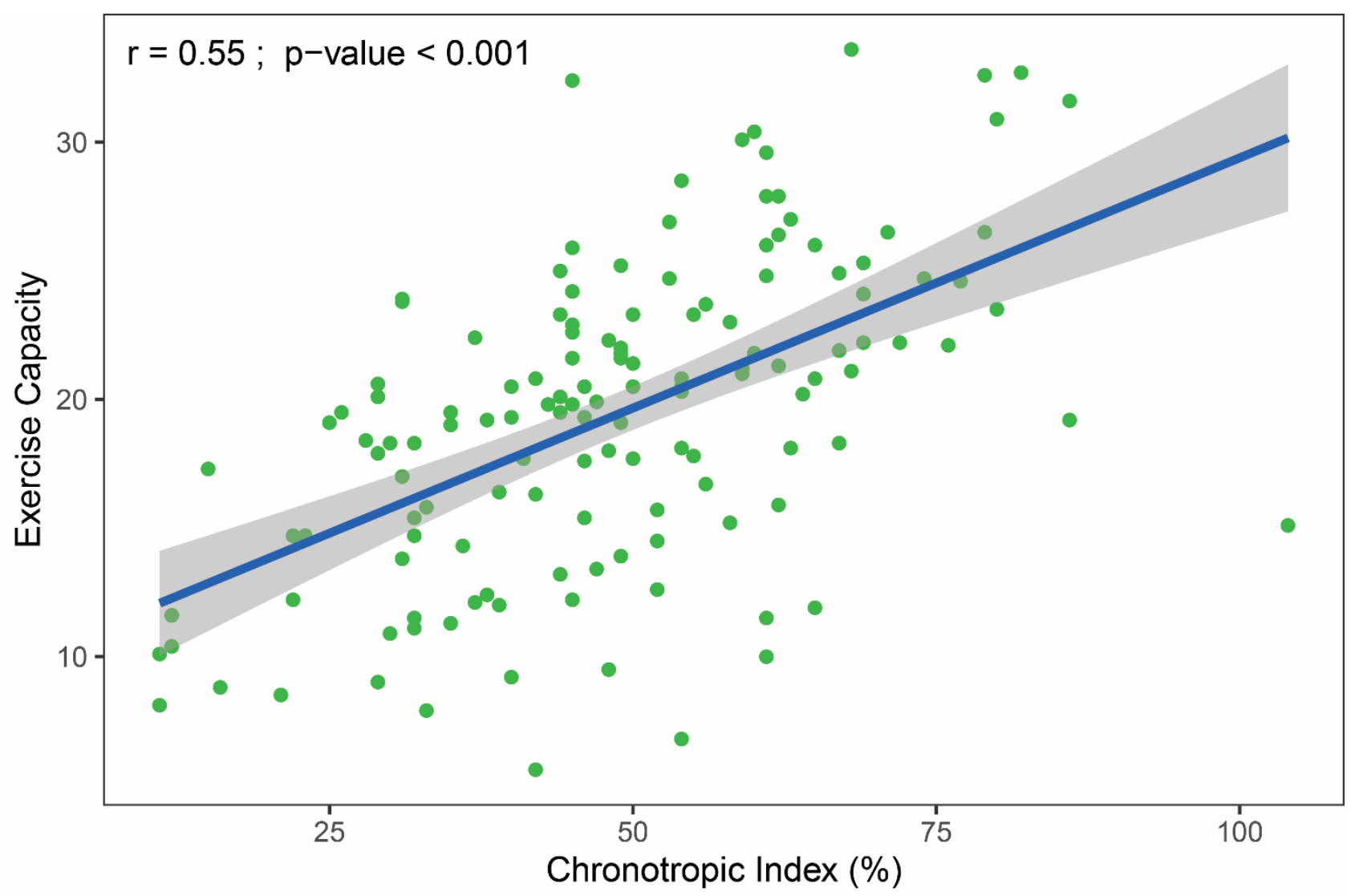

Fig. 2. The relationship between exercise capacity (oxygen uptake at peak exercise in $\mathrm{mL} / \mathrm{min} / \mathrm{kg}$ ) and chronotropic index. The gray-shaded area represents the standard error of regression line (blue). The $r$ value was calculated using Pearson correlation.

The regression analysis results are presented in Table 3 . Univariate regression analysis revealed that $\mathrm{Cl}$, male gender, treadmill exercise testing, hemoglobin concentration, and peak systolic blood pressure correlated positively with EC, while age, presence of heart failure, and diabetes mellitus / impaired fasting glucose were negatively correlated. Multivariate analysis revealed positive correlations with $\mathrm{EC}$ which remained for $\mathrm{Cl}$ and male gender, and negative correlations for age and presence of heart failure. Beta- 
blocker dose was not independently associated with EC. The partial correlation attributable to $\mathrm{Cl}$ (partial $\mathrm{R}^{2}=24.7 \%$ ) accounted for more than one-third of the variance in EC explained by the model (model adjusted $R^{2}=59.8 \%$ )

Table 2

Cardiopulmonary exercise testing parameters of study participants.

\begin{tabular}{|c|c|c|c|c|}
\hline & \multirow{2}{*}{$\begin{array}{l}\text { All patients } \\
(n=140)\end{array}$} & \multicolumn{2}{|c|}{ Chronotropic incompetence $^{a}$} & \multirow[b]{2}{*}{ p-value } \\
\hline & & $\begin{array}{c}\text { Yes } \\
(n=113)\end{array}$ & $\begin{array}{c}\text { No } \\
(n=27)\end{array}$ & \\
\hline Treadmill exercise test, $\mathrm{n}(\%)$ & $109(78)$ & $86(76)$ & $23(85)$ & 0.446 \\
\hline Cycle ergometer exercise test, n (\%) & $31(22)$ & $27(24)$ & $4(15)$ & 0.446 \\
\hline $\mathrm{VO}_{2}$ at anaerobic threshold, $\mathrm{L} / \mathrm{min}$ & $1.1 \pm 0.4$ & $1.1 \pm 0.3$ & $1.4 \pm 0.4$ & $<0.001$ \\
\hline $\mathrm{VO}_{2}$ at anaerobic threshold, $\mathrm{mL} / \mathrm{kg} / \mathrm{min}$ & $13.7 \pm 3.7$ & $13.2 \pm 3.7$ & $16.0 \pm 2.9$ & $<0.001$ \\
\hline $\mathrm{VO}_{2}$ at peak, L/min & $1.6 \pm 0.6$ & $1.5 \pm 0.5$ & $2.1 \pm 0.7$ & $<0.001$ \\
\hline $\mathrm{VO}_{2}$ at peak, $\mathrm{mL} / \mathrm{kg} / \mathrm{min}$ & $19.4 \pm 6.1$ & $18.3 \pm 5.7$ & $24.0 \pm 5.3$ & $<0.001$ \\
\hline $\mathrm{VO}_{2}$ at peak, $\mathrm{mL} / \mathrm{kg} / \mathrm{min} \%$ predicted & $73 \pm 19$ & $69 \pm 17$ & $89 \pm 18$ & $<0.001$ \\
\hline $\mathrm{CO}_{2}$ at peak, L/min & $1.8 \pm 0.8$ & $1.6 \pm 0.7$ & $2.4 \pm 0.9$ & $<0.001$ \\
\hline METs at peak & $5.5 \pm 1.7$ & $5.2 \pm 1.6$ & $6.9 \pm 1.5$ & $<0.001$ \\
\hline HR at rest (IQR), bpm & $72(64-83)$ & $72(64-82)$ & $77(67-86)$ & 0.091 \\
\hline $\mathrm{HR}$ at anaerobic threshold, bpm & $97 \pm 13$ & $95 \pm 13$ & $106 \pm 10$ & $<0.001$ \\
\hline $\mathrm{HR}$ at peak, bpm & $115 \pm 17$ & $110 \pm 15$ & $136 \pm 10$ & $<0.001$ \\
\hline $\mathrm{HR}$ at peak, \% predicted & $72 \pm 10$ & $69 \pm 8$ & $86 \pm 4$ & $<0.001$ \\
\hline Chronotropic index, \% & $48.6 \pm 17.3$ & $42.7 \pm 13.0$ & $73.1 \pm 9.3$ & $<0.001$ \\
\hline SBP at rest, $\mathrm{mmHg}$ & $127 \pm 13$ & $127 \pm 13$ & $130 \pm 13$ & 0.289 \\
\hline SBP at peak (IQR), mmHg & $170(155-180)$ & $170(150-180)$ & $180(160-190)$ & 0.075 \\
\hline RER at peak (IQR) & $1.10(1.05-1.16)$ & $1.09(1.05-1.16)$ & $1.14(1.06-1.21)$ & 0.072 \\
\hline Min. ventilation vs $\mathrm{CO}_{2}$ slope (IQR) & $24(22-28)$ & $25(23-28)$ & $23.6(21-25)$ & 0.095 \\
\hline Breathing reserve at peak (IQR), \% & $45(25-57)$ & $46(44-50)$ & $47(44-50)$ & 0.523 \\
\hline FEV $1 /$ IVC, $\%$ predicted & $93 \pm 21$ & $93 \pm 20$ & $94 \pm 23$ & 0.841 \\
\hline
\end{tabular}

Note: Values represent mean \pm SD, median (IQR; $25^{\text {th }}-75^{\text {th }}$ percentiles), or number (\%). Bold values indicate statistical significance. Abbreviations: FEV 1/IVC, forced expiratory volume in the first second/inspiratory vital capacity; HR, heart rate; IQR, interquartile range; METs, metabolic equivalents; RER, respiratory exchange ratio; SBP, systolic blood pressure; $\mathrm{VCO}_{2}$, carbon dioxide production; $\mathrm{VO}_{2}$, oxygen uptake.

${ }^{a}$ defined as chronotropic index $\leq 62 \%$. 
Table 3

Results of univariate and multivariate linear regression analyses assessing predictors of exercise capacity (EC) measured as oxygen uptake at peak exercise (VO ${ }_{2}$ peak, $\mathrm{mL} / \mathrm{min} / \mathrm{kg}$ ).

\begin{tabular}{|c|c|c|c|c|c|c|c|}
\hline & \multicolumn{3}{|c|}{ Univariate analysis } & \multicolumn{4}{|c|}{ Multivariate analysis } \\
\hline & $\begin{array}{c}\beta \text { regression } \\
\text { coefficient }\end{array}$ & $95 \% \mathrm{Cl}$ & p-value & $\begin{array}{c}\beta \text { regression } \\
\text { coefficient }\end{array}$ & $95 \% \mathrm{Cl}$ & p-value & $\begin{array}{c}\text { Explained } \\
\text { variance } \\
(\%)^{\mathrm{a}}\end{array}$ \\
\hline Chronotropic index, \% & 0.20 & 0.15 to 0.24 & $<0.001$ & 0.14 & 0.09 to 0.18 & $<0.001$ & 24.7 \\
\hline Male gender & 7.01 & 5.05 to 8.97 & $<0.001$ & 5.12 & 2.86 to 7.38 & $<0.001$ & 14.0 \\
\hline Age, years & -0.22 & -0.32 to -0.13 & $<0.001$ & -0.17 & -0.26 to -0.09 & $<0.001$ & 12.9 \\
\hline Heart failure & -4.55 & -6.52 to -2.60 & $<0.001$ & -3.35 & -4.97 to -1.72 & $<0.001$ & 11.8 \\
\hline Treadmill exercise test & 3.92 & 1.56 to 6.28 & 0.001 & & & 0.066 & 2.7 \\
\hline BB daily dose, bisoprolol equivalent, $\mathrm{mg}$ & & & 0.743 & & & 0.140 & 1.8 \\
\hline LVEF, \% & & & 0.147 & & & 0.224 & 1.2 \\
\hline Hemoglobin, g/L & 0.81 & 0.15 to 1.48 & 0.017 & & & 0.298 & 0.9 \\
\hline Serum creatinine, $\mathrm{mg} / \mathrm{dL}$ & & & 0.295 & & & 0.343 & 0.7 \\
\hline LV diastolic dysfunction, grade 2 and 3 & & & 0.108 & & & 0.413 & 0.5 \\
\hline DM / IFG & -3.25 & -5.70 to -0.80 & 0.010 & & & 0.560 & 0.3 \\
\hline Current smoker & & & 0.670 & & & 0.586 & 0.2 \\
\hline RV systolic dysfunction & & & 0.931 & & & 0.948 & 0.0 \\
\hline $\mathrm{SBP}$ at peak exercise, $\mathrm{mmHg}$ & 0.05 & 0.00 to 0.09 & 0.034 & & & & \\
\hline Hypertension & & & 0.137 & & & & \\
\hline CAD & & & 0.133 & & & & \\
\hline
\end{tabular}

Note: For multivariate analysis, $\mathrm{R}^{2}=64.1 \%$, adjusted $\mathrm{R}^{2}=59.8 \%$. Bold values indicate statistical significance.

Abbreviations: BB, beta-blocker; CAD, coronary artery disease; CI, confidence interval; DM/IFG, Diabetes mellitus/impaired fasting glucose; LV, left ventricle; LVEF, left ventricular ejection fraction; RV, right ventricle; SBP, systolic blood pressure; WMSI, wall motion score index.

${ }^{a}$ calculated as partial $R^{2}$. 
medRxiv preprint doi: https://doi.org/10.1101/2020.07.15.20149005; this version posted July 17, 2020. The copyright holder for this preprint

(which was not certified by peer review) is the author/funder, who has granted medRxiv a license to display the preprint in perpetuity.

It is made available under a CC-BY-NC-ND 4.0 International license .

\section{DISCUSSION}

This study revealed that in patients taking beta-blockers, $\mathrm{Cl}$ was the strongest independent predictor of EC and accounted for one-third of the EC variability explained by the multivariable model. Other factors, such as gender, age, and presence of heart failure, were also independent predictors of EC, although to a lesser extent. Our model revealed that echocardiographic parameters, hemoglobin and creatinine levels, the modality of the exercise test, and beta-blocker dose had no discernible effects on EC among our study population. Our results confirmed previous findings that $\mathrm{Cl}$ correlated linearly with peak $\mathrm{VO}_{2}$ (Fig. 1). ${ }^{5}$ To the best of our knowledge, this is the first study investigating which factors and to what extent can predict EC in patients taking betablockers.

Our findings also revealed significant differences in EC with regard to chronotropic incompetence defined as a $\mathrm{Cl}$ cut-off value of $62 \%$. This cut-off value has previously been shown to have prognostic significance in patients treated with betablockers. ${ }^{3}$ Age, gender, body mass index, physical activity, smoking and many comorbidities were previously examined as independently related to EC. ${ }^{25}$

Similarly to our study, the relationship between chronotropic incompetence and EC in 549 congestive heart failure patients taking beta-blockers was investigated by Magri et al. The authors concluded that chronotropic incompetence negatively correlates with EC regardless of beta-blocker daily dose. However in this study chronotropic incompetence was diagnosed as an inability to achieve $80 \%$ of $\mathrm{Cl}$ or $80 \%$ of maximum predicted HR. ${ }^{12}$

Our results do not reveal correlation between beta-blocker dose and EC. Although it has been shown that high doses of beta-blockers can cause, aggravate, or reveal latent chronotropic incompetence, ${ }^{7} 2627$ beta-blocker cessation did not normalize chronotropic response to exercise. ${ }^{28}$

Our study has some limitations as this was a single-center, observational, retrospective study with a relatively small group of mostly male patients. It included a diverse group of patients with and without heart failure. Brain natriuretic peptide plasma concentration values were not available in all patients and therefore were not included in the analyses. In the analyzed group, patients may have had chronotropic incompetence irrespective of, or induced by beta-blockers. It was also shown previously that endurance training during cardiac rehabilitation can improve chronotropic response in patients taking beta-blockers. ${ }^{10}$ Therefore, daily physical activity status can contribute in chronotropic response and EC. In our study data on physical activity status and quality of life were not available for all patients and were therefore not included in our analyses. 
medRxiv preprint doi: https://doi.org/10.1101/2020.07.15.20149005; this version posted July 17, 2020. The copyright holder for this preprint

(which was not certified by peer review) is the author/funder, who has granted medRxiv a license to display the preprint in perpetuity.

It is made available under a CC-BY-NC-ND 4.0 International license .

\section{CONCLUSIONS AND CLINICAL IMPLICATIONS}

In consecutive patients taking beta-blockers and referred for cardiopulmonary exercise testing, chronotropic incompetence, calculated as $\mathrm{Cl}$, was found to be an independent predictor of reduced EC. Cl positively and independently correlated with EC with the highest explained variance. Therefore, we recommend that for patients taking beta-blockers, $\mathrm{Cl}$ is incorporated as an exercise testing parameter, also in regular exercise stress tests. Our study revealed that beta-blocker dose was not an independent predictor of EC. Correlations between chronotropic response to exercise and beta-blocker daily doses need to be evaluated in further prospective studies. We are planning a long-term follow-up to evaluate predictors of mortality in the study group.

\section{AUTHOR CONTRIBUTIONS}

Maciej Tysarowski: conceptualization, methodology, software, formal analysis, resources, data curation, writing - review \& editing, visualization. Krzysztof Smarz: conceptualization, methodology, investigation, validation, resources, data curation, writing - original draft, review \& editing, visualization, project administration, funding acquisition. Beata Zaborska: investigation, resources, data curation. Ewa Pilichowska-Paszkiet: investigation, resources, data curation. Malgorzata SikoraFrac: investigation, resources, data curation. Andrzej Budaj: writing - review \& editing, supervision, project administration, funding acquisition. Tomasz Jaxa-Chamiec: writing - review \& editing, supervision, project administration, funding acquisition.

All authors take responsibility for all aspects of the reliability and freedom from bias of the data presented and their discussed interpretation.

\section{DATA SHARING STATEMENT}

The complete raw dataset can be accessed via the Mendeley Data repository: https://data. mendeley.com/datasets/w2jf6fr8hg/draft?a=4abca7bb-b565-4b03-bbeef5598f56282d.

\section{REFERENCES}

1. Lauer MS, Francis GS, Okin PM, et al. Impaired chronotropic response to exercise stress testing as a predictor of mortality. JAMA 1999;281:524-9.

2. Azarbal B, Hayes SW, Lewin HC, et al. The incremental prognostic value of percentage of heart rate reserve achieved over myocardial perfusion singlephoton emission computed tomography in the prediction of cardiac death and allcause mortality: superiority over $85 \%$ of maximal age-predicted heart rate. $\mathrm{J} \mathrm{Am}$ Coll Cardiol 2004;44(2):423-30. doi: 10.1016/j.jacc.2004.02.060 [published Online First: 2004/07/21] 
medRxiv preprint doi: https://doi.org/10.1101/2020.07.15.20149005; this version posted July 17, 2020. The copyright holder for this preprint

(which was not certified by peer review) is the author/funder, who has granted medRxiv a license to display the preprint in perpetuity. It is made available under a CC-BY-NC-ND 4.0 International license .

3. Khan MN, Pothier CE, Lauer MS. Chronotropic incompetence as a predictor of death among patients with normal electrograms taking beta blockers (metoprolol or atenolol). Am J Cardiol 2005;96(9):1328-33. doi: 10.1016/j.amjcard.2005.06.082 [published Online First: 2005/10/29]

4. Myers J, Tan SY, Abella J, et al. Comparison of the chronotropic response to exercise and heart rate recovery in predicting cardiovascular mortality. Eur $J$ Cardiovasc Prev Rehabil 2007;14(2):215-21. doi:

10.1097/HJR.0b013e328088cb92 [published Online First: 2007/04/21]

5. Dobre D, Zannad F, Keteyian SJ, et al. Association between resting heart rate, chronotropic index, and long-term outcomes in patients with heart failure receiving beta-blocker therapy: data from the HF-ACTION trial. Eur Heart $J$ 2013;34(29):2271-80. doi: 10.1093/eurheartj/ehs433 [published Online First: 2013/01/15]

6. Engeseth K, Hodnesdal C, Grundvold I, et al. Temporal Reduction in Chronotropic Index Predicts Risk of Cardiovascular Death Among Healthy Middle-Aged Men: a 28-Year Follow-Up Study. J Am Heart Assoc 2016;5(12) doi:

10.1161/JAHA.116.004555 [published Online First: 2016/11/25]

7. Brubaker PH, Kitzman DW. Chronotropic incompetence: causes, consequences, and management. Circulation 2011;123(9):1010-20. doi:

10.1161/CIRCULATIONAHA.110.940577 [published Online First: 2011/03/09]

8. Laforgia P, Bandera F, Alfonzetti E, et al. Exercise chronotropic incompetence phenotypes the level of cardiovascular risk and exercise gas exchange impairment in the general population. An analysis of the Euro-EX prevention trial. Eur J Prev Cardiol 2019:2047487319863506. doi: 10.1177/2047487319863506 [published Online First: 2019/07/28]

9. Vallebona A, Gigli G, Orlandi S, et al. Heart rate response to graded exercise correlates with aerobic and ventilatory capacity in patients with heart failure. Clin Cardiol 2005;28(1):25-9. doi: 10.1002/clc.4960280107 [published Online First: 2005/02/12]

10. Takano N, Takano H, Fukuda T, et al. Relationship between chronotropic incompetence and beta-blockers based on changes in chronotropic response during cardiopulmonary exercise testing. Int J Cardiol Heart Vasc 2015;6:12-18. doi: 10.1016/j.jjcha.2014.11.002 [published Online First: 2014/12/03]

11. Jorde UP, Vittorio TJ, Kasper ME, et al. Chronotropic incompetence, beta-blockers, and functional capacity in advanced congestive heart failure: time to pace? Eur $J$ Heart Fail 2008;10(1):96-101. doi: 10.1016/j.ejheart.2007.11.006 [published Online First: 2007/12/22]

12. Magri D, Palermo P, Cauti FM, et al. Chronotropic incompentence and functional capacity in chronic heart failure: no role of beta-blockers and beta-blocker dose. 
medRxiv preprint doi: https://doi.org/10.1101/2020.07.15.20149005; this version posted July 17, 2020. The copyright holder for this preprint

(which was not certified by peer review) is the author/funder, who has granted medRxiv a license to display the preprint in perpetuity. It is made available under a CC-BY-NC-ND 4.0 International license .

Cardiovasc Ther 2012;30(2):100-8. doi: 10.1111/j.1755-5922.2010.00184.x [published Online First: 2010/06/18]

13. Al-Najjar Y, Witte KK, Clark AL. Chronotropic incompetence and survival in chronic heart failure. Int J Cardiol 2012;157(1):48-52. doi: 10.1016/j.ijcard.2010.11.018 [published Online First: 2010/12/28]

14. Guazzi M, Adams V, Conraads V, et al. EACPR/AHA Scientific Statement. Clinical recommendations for cardiopulmonary exercise testing data assessment in specific patient populations. Circulation 2012;126(18):2261-74. doi: 10.1161/CIR.0b013e31826fb946 [published Online First: 2012/09/07]

15. Arena R, Myers J, Williams MA, et al. Assessment of functional capacity in clinical and research settings: a scientific statement from the American Heart Association Committee on Exercise, Rehabilitation, and Prevention of the Council on Clinical Cardiology and the Council on Cardiovascular Nursing. Circulation 2007;116(3):329-43. doi: 10.1161/CIRCULATIONAHA.106.184461 [published Online First: 2007/06/20]

16. Fletcher GF, Ades PA, Kligfield $P$, et al. Exercise standards for testing and training: a scientific statement from the American Heart Association. Circulation 2013;128(8):873-934. doi: 10.1161/CIR.0b013e31829b5b44 [published Online First: 2013/07/24]

17. Ponikowski P, Voors AA, Anker SD, et al. 2016 ESC Guidelines for the diagnosis and treatment of acute and chronic heart failure: The Task Force for the diagnosis and treatment of acute and chronic heart failure of the European Society of Cardiology (ESC)Developed with the special contribution of the Heart Failure Association (HFA) of the ESC. Eur Heart J 2016;37(27):2129-200. doi: 10.1093/eurheartj/ehw128 [published Online First: 2016/05/22]

18. Lang RM, Bierig M, Devereux RB, et al. Recommendations for chamber quantification: a report from the American Society of Echocardiography's Guidelines and Standards Committee and the Chamber Quantification Writing Group, developed in conjunction with the European Association of Echocardiography, a branch of the European Society of Cardiology. J Am Soc Echocardiogr 2005;18(12):1440-63. doi: 10.1016/j.echo.2005.10.005 [published Online First: 2005/12/27]

19. Lang RM, Badano LP, Mor-Avi V, et al. Recommendations for cardiac chamber quantification by echocardiography in adults: an update from the American Society of Echocardiography and the European Association of Cardiovascular Imaging. J Am Soc Echocardiogr 2015;28(1):1-39 e14. doi:

10.1016/j.echo.2014.10.003 [published Online First: 2015/01/07]

20. Nagueh SF, Smiseth OA, Appleton CP, et al. Recommendations for the Evaluation of Left Ventricular Diastolic Function by Echocardiography: An Update from the American Society of Echocardiography and the European Association of 
medRxiv preprint doi: https://doi.org/10.1101/2020.07.15.20149005; this version posted July 17, 2020. The copyright holder for this preprint

(which was not certified by peer review) is the author/funder, who has granted medRxiv a license to display the preprint in perpetuity. It is made available under a CC-BY-NC-ND 4.0 International license .

Cardiovascular Imaging. J Am Soc Echocardiogr 2016;29(4):277-314. doi:

10.1016/j.echo.2016.01.011 [published Online First: 2016/04/03]

21. ATS/ACCP Statement on cardiopulmonary exercise testing. Am J Respir Crit Care Med 2003;167(2):211-77. doi: 10.1164/rccm.167.2.211 [published Online First: 2003/01/14]

22. Gibbons RJ, Balady GJ, Bricker JT, et al. ACC/AHA 2002 guideline update for exercise testing: summary article: a report of the American College of Cardiology/American Heart Association Task Force on Practice Guidelines (Committee to Update the 1997 Exercise Testing Guidelines). Circulation 2002;106(14):1883-92. doi: 10.1161/01.cir.0000034670.06526.15 [published Online First: 2002/10/03]

23. Wasserman K, Hansen JE, Sue DY, Stringer WW, Sietsema KE, Sun X, Whipp BJ. Normal values. Principles of exercise testing and interpretation including pathophysiology and clinical applications. 5th ed. Philadelphia: Wolters Kluwer/Lippincott Williams \& Wilkins 2012:154 - 80.

24. Astrand I. Aerobic work capacity in men and women with special reference to age. Acta Physiol Scand Supp/ 1960;49(169):1-92. [published Online First: 1960/01/01]

25. Doherty P, Alotaibi JF. Evaluation of determinants of walking fitness in patients attending cardiac rehabilitation. BMJ Open Sport \&amp; Exercise Medicine 2017;2(1):e000203. doi: 10.1136/bmjsem-2016-000203

26. Gauri AJ, Raxwal VK, Roux L, et al. Effects of chronotropic incompetence and betablocker use on the exercise treadmill test in men. Am Heart $J$ 2001;142(1):13641. doi: 10.1067/mhj.2001.115788 [published Online First: 2001/06/30]

27. Witte KK, Cleland JG, Clark AL. Chronic heart failure, chronotropic incompetence, and the effects of beta blockade. Heart 2006;92(4):481-6. doi: 10.1136/hrt.2004.058073 [published Online First: 2005/09/15]

28. Hirsh BJ, Mignatti A, Garan AR, et al. Effect of beta-blocker cessation on chronotropic incompetence and exercise tolerance in patients with advanced heart failure. Circ Heart Fail 2012;5(5):560-5. doi: 10.1161/CIRCHEARTFAILURE.112.967695 [published Online First: 2012/08/03] 